\title{
Impact of Credit Risk Transfer Techniques on Lending Behavior of Conventional \& Islamic Banks in Pakistan
}

\begin{abstract}
Yusra Saeed ${ }^{1}$, Huma Ayub*1
Abstract

Application of risk management techniques gain significant importance after the financial crises of 2008. Banks adopt contemporary risk management techniques to eliminate credit risk associated with the enlargement of their lending volume. The present study aims to analyze the impact of credit derivatives on lending/financing behavior of conventional and Islamic banks of Pakistan. The study used comparative analysis by employing random effect model for the sample of 20 conventional banks and pooled OLS regression on sample size of 5 Islamic banks for the period of 20062016. Results of the study show that conventional banks effectively increase their lending volumes by utilizing risk transfer techniques. However, Islamic banks are still at its infancy in utilizing risk transfer techniques due to shariah restrictions. The study recommends policy implications for Islamic bank to introduce innovative shariah compliant hedging instruments to boost their financing portfolios.
\end{abstract}

Keywords: Lending Behavior, Bank Credit Supply, Credit Risk Transfer, Credit Derivatives.

\section{Introduction}

The financial crises in 2008 exposed high insolvency costs which motivate both conventional and Islamic banks to implement risk management procedures. These risk management procedures facilitate banks to achieve desire results in their portfolio by the transmission of risk. Innovation in financial markets and development of new financial instruments such as credit derivatives and collateralized debt obligations (CDO) lead to better diversification of portfolios by providing a wider range of techniques for risk management (Cebenoyan \& Strahan, 2004; Greenspan, 2005). Credit derivatives are financial instruments used to transfer credit risk of loans and other assets. There are various types of credit derivatives such as options, forwards and swaps etc. Utilization of these tools raised the question by conventional as well as Islamic banks regarding their impact on lending volume (DUFFIE, 2007). Market analysts and risk managers stress on the importance of these new techniques as they empower banks to divest their risks and ensure the growth in lending (Forum, 2008; Hirtle, 2009; Wagner \& Marsh, 2006).

https://doi.org/10.30537/sijmb.v4i2.108

${ }^{1}$ Department of Business Administration, Fatima Jinnah Women University, Pakistan.

* Corresponding Author: huma_ayub@fjwu.edu.pk 
Islamic banks acknowledge the importance of credit risk transfer techniques to actively manage financial risks. However, they are reluctant to use these techniques due to shariah controversies (Ahmed \& Khan, 2007). Literature shows that Islamic banks procedures involved high credit risk due to trading with shariah rules as well as with government laws in contrast to these of conventional banks (Zahan \& S Kenett, 2012). Therefore, Islamic banks may need to employ innovative shariah compliant risk management practices to divest their existing and projected credit risk. Till to date, literature on analyzing the comparative impact of credit risk transfer techniques on lending behavior of conventional and Islamic banks is scarce. More precisely, there is a limited work available on this topic in the context of Pakistan, where the parallel banking system exists. The impressive growth of Islamic banking share in Pakistan also motivates the researcher to conduct the comparative analysis by examining the impact of risk transfer techniques (derivatives) on lending behavior of conventional as well Islamic banks of Pakistan.

The study provides policy implications to regulators and risk managers in conventional and Islamic banks. As the results of study confirmed the significance of using credit risk mitigation techniques to increase the lending volume of conventional banks. Therefore, risk managers in conventional banks need to focus on introducing innovative derivative tools to support their lending growth. However, the study also suggests the Islamic banks to develop Shariah complaint derivative products to enhance their financing performance. For future research, this study extends the literature on the comparative credit risk transfer/management techniques.

The remaining part of the study is structured as the literature review presents the existing knowledge on the credit risk transfer instruments and techniques. Third section discusses the methodology of the study. Moreover, next section comprises the discussion based on estimated results connecting them to the existing knowledge specified in literature review. The last section presents conclusion along with the recommendations of the study.

\section{Literature Review}

Risk management is imperative for the performance of banks. Banks increasingly recognized the necessity to estimate and supervise the risk associated in their lending portfolio by using quantitative methods. Banks realized that concentration of credits can adversely influence their financial efficiency. They also employ risk derivatives concerning the portfolio theory to protect customer relationships and mainly to transfer risk proficiently (Kairu, 2009). Haensel and Krahnen (2007) Conclude that risk appetite of issuing bank can be enhanced by use of modern risk instruments. Literature shows that there are several innovative derivative products such as futures, forwards, swaps, options etc. that can improve the lending behavior of banks. These derivative products are used by conventional banks to cope up with their credit risk (DUFFIE, 2007). With respect to the innovation in risk transfer instruments, Goderis, Marsh, Castello, and 
Wagner (2007) conducted a study by including all the banks in the sample which are applying risk mitigation techniques to remove credit risk from their borrowers. By applying the panel data approach, they found that modern risk mitigation tools have positive influence on the lending growth of banks. It is identified from the previous empirical studies that to mitigate the risk exposure of firm, derivatives are widely in exercise. ${ }^{2}$ Allen and Gale (2004) Concluded that in times of distress no doubt these developments (derivative products) enhance the benefits by increasing the capacity of banks to expand their lending activities.

Academic studies in context of conventional banking sector concentrate more on the trend of risk transfer as compare to Islamic sector. Due to some shariah controversies this phenomenon exhibits little concentration by Islamic banks. Islamic banks may be expected to face two types of risks: risks that are similar to those faced by traditional financial intermediaries and risks that are unique owing to their compliance with the shariah. Furthermore, Islamic banks are constrained in using some of the risk mitigation instruments that their conventional counterparts use as these are not allowed under Islamic commercial law due to the presence of gharar and element of riba (Ahmed \& Khan, 2007).

Khan et al. (2016) Suggests to the fiqh scholars to review their position and allow the Islamic banks to use these contemporary contracts such as future. Swaps and options for hedging ${ }^{3}$. Ali (2015) and Zakaria and Ismail (2007) constructed the empirical and conceptual setting to examine the impact of CRT on lending and financial stability of Islamic banks. The results of their study demonstrated that Islamic banks behave like conventional banks in context of using risk mitigation techniques. Many empirical studies discuss the evolution of financial sector and factors influencing the growth of credit in commercial banks. However, less concentration is paid in the context of developing economies like Pakistan. Financial market of Pakistan has enormous space for improvement of derivatives. Banking organizations need to enhance their capabilities to use a range of derivative products (S. Akhtar, 2006). The outstanding improvements in fundamental derivatives instrument have been witnessed during 20042005 in Pakistan (R. I. McKinnon, 2010).

Afza and Alam (2011) and Khan et al. (2016) conducted quantitative research to examine the factors that affect the decision of firms to use the foreign exchange derivative (FX). This research is conducted by taking 86 non-financial firms listed in

\footnotetext{
${ }^{2}$ Nwankwo; (Chodechai, 2004); (Chernykh \& Theodossiou, 2015; Olokoyo, 2011); Ansari (2006); (Aisen \& Franken, 2010; Berrospide \& Edge, 2010; Rai \& Kamil, 2010; Stepanyan \& Guo, 2011); Grodzicki et al. (2010); (R. I. McKinnon, 2010); (Demirgüç-Kunt \& Levine, 2004).

${ }^{3}$ Hedging contracts like forward and future contracts, repurchase agreements, forward rate agreements etc. such contracts are adjustable according to shariah perspective. Like future contracts can be made using salam for animals, mineral oils etc.
}

Sukkur IBA Journal of Management and Business - SIJMB | Volume 4 No. 2 July - December 2017 @ Sukkur IBA University 
KSE for the time duration of 2004-2007. In Pakistani context, many studies (e.g. (Afza \& Alam, 2011; Ahmad, Malik, \& Humayoun, 2010; Imran \& Nishat, 2013)) tried to explore different forms of risk mitigation instruments and also explain how they are utilized for hedging purposes. But very few studies focus on the comparative analysis of conventional and Islamic banks on the risk mitigation techniques and its influence on lending behavior of Pakistani banking sector. Afza and Alam (2011)) and Ahmed and Khan (2007) in their studies examined factors that affected the decision of firm to utilize FX derivatives, without considering other forms of derivatives i.e. futures, forwards and swaps and their impact comparatively on the lending behavior of conventional and Islamic banks. Present manuscript aims to fill up this gap by considering the influence of these innovative instruments on the lending behavior of Pakistani financial sector by including conventional as well as Islamic banks.

\section{Methodology}

This section provides the research design and the method for the gathering and analysis of data. This section represents the model specification, estimation technique and support test for the data analysis and interpretation.

\subsection{Model specification}

Literature shows that there is a positive effect on credit growth due to the usage of modern risk management practices. From literature it is analyzed that by using derivative instruments lending volume of banks increases (Ali, 2015; Rodríguez \& Carbó, 2000). The present study uses two proxies for lending behavior i.e. gross financing to total assets (GF), net financing to total assets (NF). By adopting the methodology of Afza and Alam (2011) and Khan et al. (2016), this study takes the nominal sum of credit derivative instruments as a proxy of risk transfer techniques. Further some bank specific factors and macro-economic factors are also included in the equation (1) that is; capital ratio, profitability ratio, liquidity ratio, GDP, interest rate and exchange rate.

It is hypothesized in the current study and also proved by the previous studies that bank specific variables have impact on the lending behavior of banks. Moreover economic development encourages the expansion of credit by financial institutions ${ }^{4}$.

\subsection{Econometric Model}

The econometric model for this study is;

$$
\begin{gathered}
\mathrm{LB}_{\mathrm{it}}=\alpha+\beta_{1} \mathrm{CRT}+\beta_{2}(\mathrm{ROA})_{\mathrm{it}}+\beta_{3}(\mathrm{LIQ})_{\mathrm{it}}+\beta 4(\mathrm{CAP})_{\mathrm{it}}+\beta_{5} \mathrm{GDP}+\beta_{6} \mathrm{IR}_{\mathrm{it}} \\
+\beta_{7} \mathrm{ER}_{\mathrm{it}}+\varepsilon_{i \mathrm{it}} \ldots \ldots(1)
\end{gathered}
$$

${ }^{4}$ Paroush and Schreiber (2008); M. F. Akhtar, Ali, and Sadaqat (2011); Ali (2015); (Gurley \& Shaw, 1967); (R. McKinnon \& Shaw, 1973); (R. I. McKinnon, 2010) and present researchers like (Rehman \& Cheema, 2013) and (Beck, 2000). 
Where;

$\mathrm{LB}_{\text {it }}=$ Lending Behavior; $\mathrm{CRT}=$ Credit Risk Transfer Instrument (Derivatives); $\mathrm{ROA}=$ Profitability Ratio; LIQ = Liquidity Ratio; $\mathrm{CAP}=$ Capital Ratio; GDP = Gross Domestic Product Growth; IR = Interest Rate; ER = Exchange Rate; $\varepsilon=$ Error Term.

\subsection{Data}

The sample of study comprises all the commercial banks (conventional and Islamic), which fully represent the whole banking sector of Pakistan for determination of risk transfer techniques. The time horizon of sample is CY 2006-2016. The data is extracted from annual reports of banks; moreover the financial statement analysis of banks by SBP for years 2006-10 and 2011-15 is also utilized for calculation of ratios. While the Macroeconomic data is taken from the international financial statistics (IFS) database from the website of the international monetary fund (IMF) and the World Bank data base.

\subsection{Estimation Techniques}

The study follows the data analysis techniques used by many previous researchers i.e. panel data technique used by (Angora \& Roulet, 2011; Ramzan \& Zafar, 2014). The study uses a random effect model for conventional banks on the basis of the Hausman specification test, while pooled OLS is used for Islamic banks due to small number of banks. The data is analyzed using STATA software for econometric estimation.

\section{Results and Discussion}

Descriptive statistics computation of all variables that are used in regression analysis is shown in Table1. The table includes statistics of all dependent, independent and control variables for the time period of 2006 to 2016 . The mean value of gross lending (GL) is 47.970 with standard deviation of 11.542 , for 2006 to 2016 . The mean value of GL depicted the volume of gross lending adopted by banks during this period of time. The other measure of lending (NL) - net lending- is averaged at 43.866, with standard deviation of 10.777, showed the strong position of Pakistani commercial banks in maintaining high financial position. The derivative (DR) variable clocked an average of 16.074, with the standard deviation of 3.931 for years 2006-2016. The mean value of $160 \%$ indicated that the banks in Pakistan largely used derivatives to hedge their funds. ROA indicates the average value of 1.204 (120.4\%) with deviation of 2.732, while liquidity ratio (LR) averaged at 10.265 with deviation of 4.550.The capitalization measure (CAP) indicated an Average value of $13.432 \%$. The macroeconomic variables (GDP, IR, and ER) indicate the mean value of 3.981 for GDP, IR has an average of 1.611 with deviation of 4.689 in years 2006-2016. Moreover the exchange rate (ER) ranged between 94.5 to 122.51 with the average of 104.432 and standard deviation of 8.900 . 
Table 1: Descriptive Statistics of the Study Variables

\begin{tabular}{ccccccc}
\hline Variables & Min & Max & Mean & Std. Dev. & VIF & Tolerance \\
\hline GL & 1 & 82 & 47.970 & 11.542 & - & - \\
NL & 1.34 & 70.86 & 43.866 & 10.777 & - & - \\
DR & 0 & 21.707 & 16.074 & 3.931 & 1.17 & 0.851 \\
ROA & -10.37 & 11.17 & 1.205 & 2.732 & 1.06 & 0.940 \\
LR & 1.13 & 28.27 & 10.265 & 4.550 & 1.09 & 0.951 \\
CR & 0.29 & 72.72 & 13.432 & 12.371 & 1.13 & 0.887 \\
GDP & 1.61 & 6.18 & 3.981 & 1.531 & 1.64 & 0.610 \\
IR & -6.77 & 7.13 & 1.611 & 4.689 & 1.54 & 0.648 \\
ER & 94.5 & 122.51 & 104.432 & 8.900 & 2.42 & 0.413 \\
\hline
\end{tabular}

Additionally, Table 1 shows the Variance Inflation Factors for independent variables. As the general rule of thumb the value greater than 4 signifies the issue of multicollinearity, the above table shows that there is no problematic collinearity exits in the variables.

Table 2: Correlation Matrix of study variables

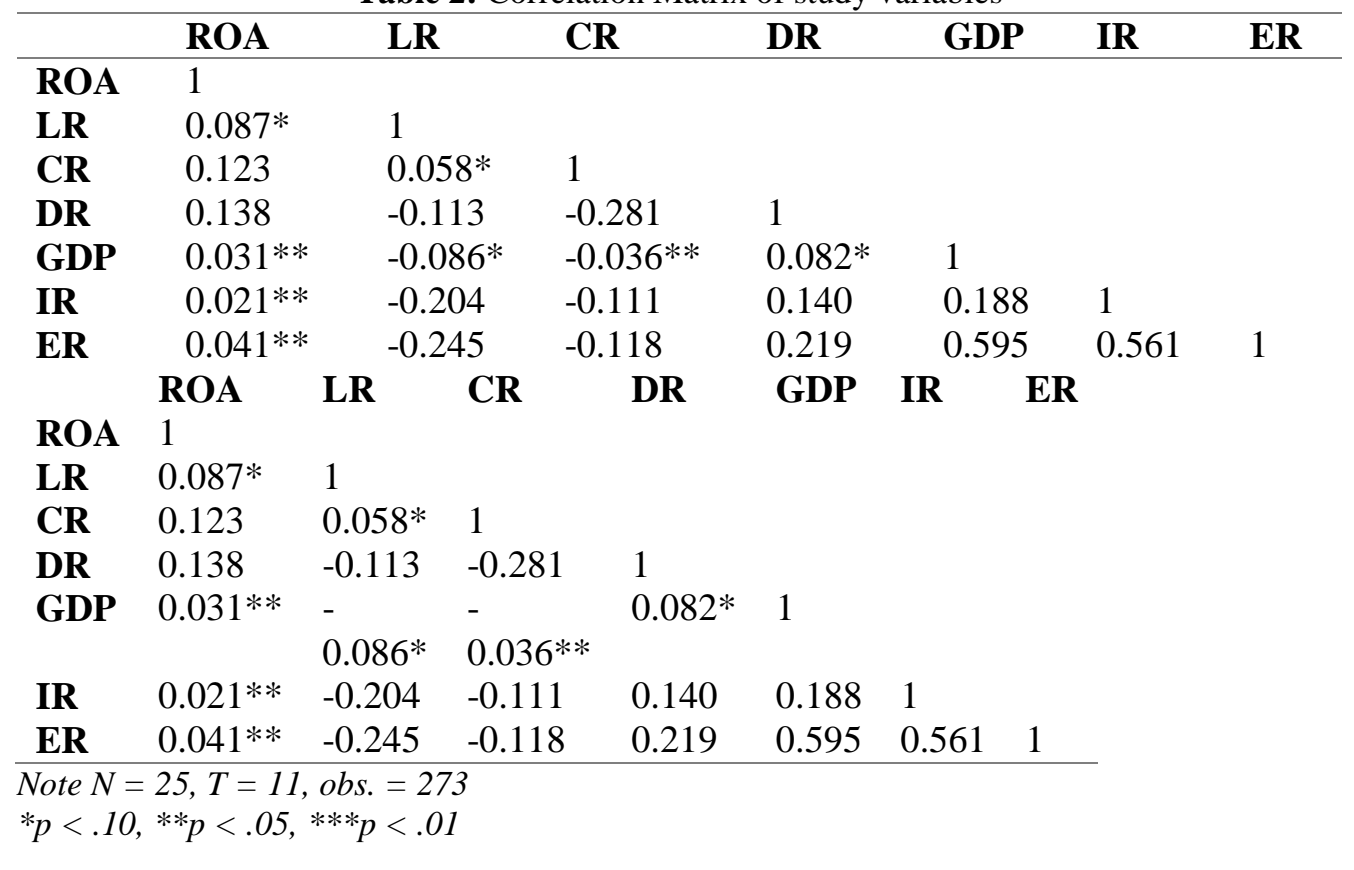

Pearson correlation Matrix used for independent variables is shown in Table 2. This matrix depicts the strength of linear relationship between two variables particularly between independent variables. The problem of multi collinearity exits if there is strong correlation (coefficient $>0.70$ ) between independent variables (Farrar \& Glauber, 1967). The variable in his study are not perfectly correlated to each other as the coefficients are less than 0.70 . However, there is moderate correlation between ER 
(Exchange Rate) and GDP (60\%) and ER and IR (56\%). Thus the matrix value indicates no issue of Multi- collinearity and proven grounds of hypothesis testing.

The regression results for random effects after Hausman test are given in the table 3 and 4 which provide details about the regression coefficients and the significance level of independent variables for both models including GL and NL. As there is an issue of serial correlation in both models which is shown in table 6, to cater for these issues the White corrected standard errors were used for estimation introduced by (White, 1980). Table 3 shows the comparative results of conventional and Islamic banks. Although the credit risk exposure is the same for both conventional and Islamic banks Ahmed and Khan (2007), there are some structural and operational differences existing between them. Further, different regression estimation i.e. pooled Ordinary Least Squares (OLS) regression estimation is used to analyze the results of Islamic banks due to small sample size. This estimation has extensively been used in previous studies (Cucinelli (2013); Roman and Şargu (2014)), while for conventional banks the random effects estimation is used.

Table 3: Results of the Random effect \& Pooled OLS Regression with (GL) Model

\begin{tabular}{lllllll}
\hline $\begin{array}{l}\text { Conventional Bank } \\
\text { (Random Effects Results) }\end{array}$ & & & \multicolumn{3}{l}{$\begin{array}{l}\text { Islamic Banks } \\
\text { (Pooled }\end{array}$} \\
\hline Variables & B & R.SE & z-Stat & $\beta$ & R.SE & t-Stat \\
Constant & 91.228 & 11.688 & $7.81^{* * *}$ & -22.30 & 27.84 & -0.80 \\
ROA & 0.255 & 0.427 & $0.65^{*}$ & 1.168 & 0.811 & 1.44 \\
LR & 0.365 & 0.416 & 0.88 & 0.368 & 0.261 & 1.41 \\
CR & 0.032 & 0.114 & 0.28 & 0.266 & 0.185 & 1.44 \\
DR & 0.860 & 0.250 & $3.44^{* * *}$ & 0.202 & 0.434 & 0.47 \\
GDP & -0.571 & 0.533 & -1.07 & -2.041 & 1.318 & -1.55 \\
IR & -0.071 & 0.087 & -0.81 & 0.224 & 0.403 & 0.56 \\
ER & -0.565 & 0.096 & $-5.87^{* * *}$ & 0.624 & 0.278 & $2.24 * *$ \\
$\mathrm{R}^{2}$ & 0.273 & & & 0.255 & & \\
Wald Chi $/$ F- & $131.13^{* * *}$ & & & $2.20 * * *$ & & \\
statistics & & & & & & \\
\hline
\end{tabular}

Note $* 1 . N=20, T=11$, obs. $=220$

Note ${ }^{* 2} . N=5, T=11$, obs. $=53$

${ }^{*} p<.10,{ }^{* *} p<.05, * * * p<.01$ 
Table 4: Results of the Random effect \& Pooled OLS Regression with (NL) Model

\begin{tabular}{lllllll}
\hline $\begin{array}{l}\text { Conventional Bank } \\
\text { (Random Effects Results) }\end{array}$ & & \multicolumn{3}{l}{$\begin{array}{l}\text { Islamic Banks*2 } \\
\text { (Pooled OLS Results) }\end{array}$} \\
\hline Variables & B & R.SE & t-Stat & B & R.SE & t-Stat \\
Constant & 86.438 & 8.958 & $9.65 * * *$ & -14.261 & 27.95 & -0.51 \\
ROA & 0.631 & 0.395 & $1.65^{*}$ & 1.286 & 0.814 & 1.58 \\
LR & 0.265 & 0.350 & 0.76 & 0.316 & 0.262 & 1.20 \\
CR & 0.039 & 0.090 & 0.43 & 0.302 & 0.186 & 1.62 \\
DR & 0.864 & 0.202 & $4.26 * * *$ & 0.252 & 0.436 & 0.58 \\
GDP & 0.053 & 0.496 & 0.11 & -1.690 & 1.323 & -1.28 \\
IR & -0.125 & 0.069 & -1.79 & 0.234 & 0.405 & 0.58 \\
ER & -0.585 & 0.082 & $-7.09 * * *$ & 0.512 & 0.279 & $1.83 *$ \\
R & & & & 0.219 & & \\
Wald & 0.285 & & & $1.81 *$ & & \\
Chi ${ }^{2} / F-$ & & & & & & \\
statistics & & & & & &
\end{tabular}

Note ${ }^{* 1} . N=21, T=11$, obs. $=231$

Note ${ }^{* 2} . N=5, T=11$, obs. $=55$

$* p<.10, * * p<.05, * * * p<.01$

Table 3 and 4 provides the comparative result of regression estimates for gross lending ratio (GL) and Net Lending (NL) for conventional and Islamic banks separately. The result of credit risk measures (DR) confirms the solidness of estimation with significant coefficient value $(0.860)$ and $(0.864)$ at $1 \%$ significance level for both models in case of conventional banks. Similar results are evident from the work done by (Afza and Alam (2011); Arping (2004); Nicolo and Pelizzon (2006); Wagner and Marsh (2006)) which implies that CRT derivatives enhance the welfare of financial system by helping banks to diversify and hedge their credit risk and become more efficient and stable. But in the robustness check derivative become insignificant for Islamic banks as also evident from the work of (Ahmed \& Khan, 2007; Hirtle (2009)), who implies the negative effect of derivatives on new lending. The results suggest differences on the utilization of derivatives. This may also be due to difference across types of banks i.e. some banks are more active than others in managing their risks and this affects the usage of derivatives (Cebenoyan \& Strahan, 2004; Cihák \& Hesse, 2008). Similarly it is observe from present study that Islamic banks are less inclined towards using modern techniques of risk mitigation because most of the conventional derivative instruments (swaps, options, and futures) do not conform to shariah. This implies that only conventional sector has significant influence of derivatives on its lending behavior in Pakistan. 


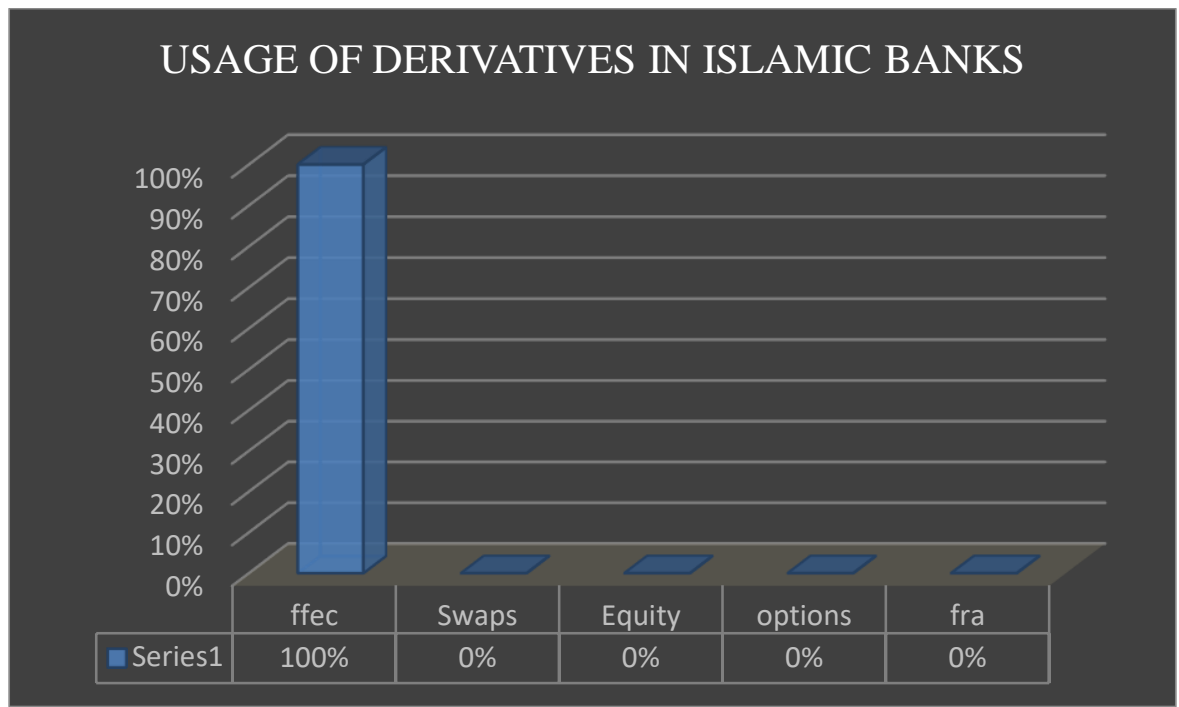

Figure 1: Usage of different types of derivatives in Islamic bank Source: Author's own

Usage of different forms of derivatives is shown in the figure 1, where it is clear that just future and forward contracts are used as derivatives by Islamic banking sector. They are not utilizing other forms of derivatives due to shariah obligations. However, they should build some innovative strategies to make the other forms of derivatives shariah compliant as also practised in other Muslims countries.

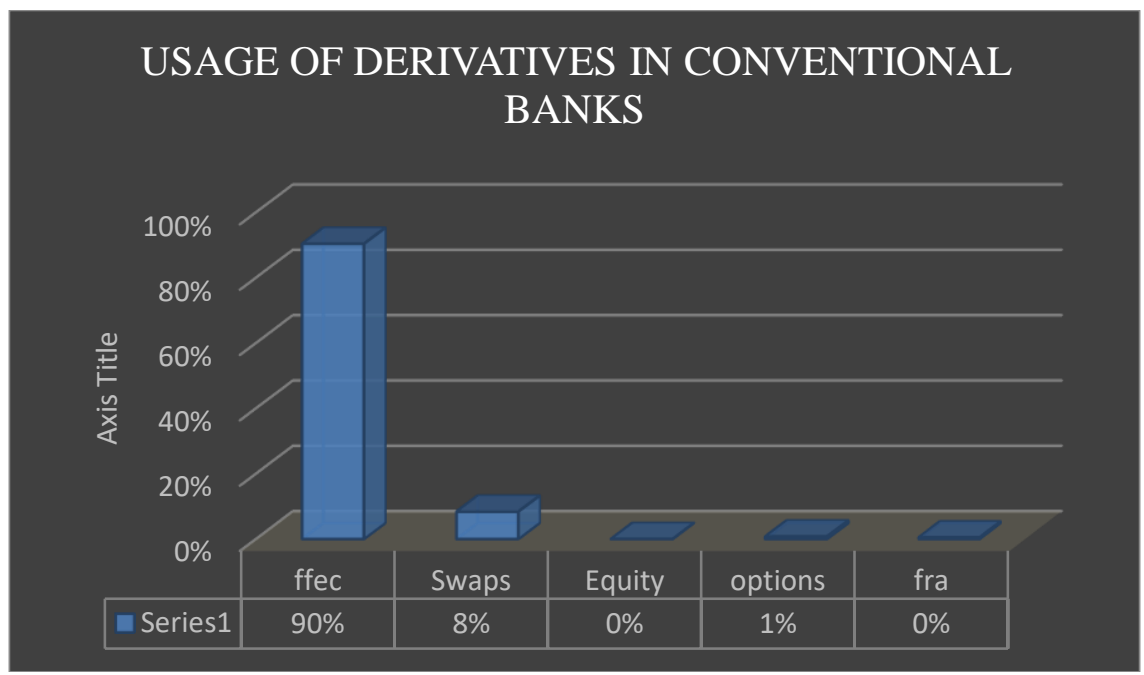

Figure 2: Usage of different types of derivatives in conventional bank Source: Author's own 
As it is clear from figure 2 that future and forward contracts are also very common in use by conventional banks. Other forms are used in a very limited quantity almost 0 and $1 \%$ and these other types are only used by public sector. Conventional banks should also consider other types as by utilizing other techniques their lending performance can be increase. The result of present study shows the insignificant relationship of capital with the lending behavior which is consistent with the results of (Cucinelli, 2013). Consequences of present study are opposed to the theoretical extrapolation of (Ali (2015); Bedendoa and Bruno (2009); Bokpin and Isshaq (2009)), who debates that enhanced capitalization associations prefer to downsizing their credit threats via credit derivatives.

For Islamic banks, the return on assets variable became insignificant for both GL and NL models, demonstrating that ROA has no impact on the lending behavior of Islamic banks conflicting with the literature. In conventional banks ROA indicates significant relationship having positive coefficient value of 0.255 in GL and 0.631 in NL at $10 \%$ significance level. This means $98 \%$ growth occurs in bank's lending level by $10 \%$ increase in ROA. This implies that ROA is a significant predictor of lending behavior. The results of relationship of profitability with lending behavior are according to literature, where in Pakistan, the profitability is positive connected to lending behavior, consistent with the study of (Roman \& Şargu, 2014). However, it becomes insignificant when analyzed in Islamic sector. These results are consistent with (M. F. Akhtar et al., 2011; Ramzan and Zafar (2014)). Liquidity ratio (LR) shows the robustness of results, where it became insignificant showing that liquidity has no impact on the lending behavior of Pakistani banks. SBP is functioning on providing various liquidity management resolutions for the industry. To dealing with liquidity in Islamic banks, SBP has launched Bai Muajjal of sukuk during the year as a significant tool.

Capital ratio (CR) remained insignificant for Islamic and conventional banks. The gross domestic product (GDP) and interest rate (IR) remained insignificant for both type of banks in both regression models i.e. GL and NL. ER shows negatively significant relation for conventional banks at $1 \%$ level in both models. This is opposed to our expectations and thus, inconsistent with the work of (Ali, 2015). But ER changed its relation with Islamic banks to some extent by showing positive significant results having beta value 0.642 at $5 \%$ significance level in GL and beta value of 0.512 at $1 \%$ significance level in NL model. The results support the previous studies of (Chodechai, 2004) and (Olokoyo, 2011). Results indicate that exchange rate affects the lending expansion of only Islamic banks greatly as compared to other economic indicators.

\section{Post-Estimation and Diagnostic Tests}

To check the issue heteroscedasticity in variables that are under study, the test used is proposed by Breusch and Pagan (1979), which was later on extended by (Cook \& Weisberg, 1983). In this test, null hypothesis refers the homoscedasticity, while the 
alternative hypothesis signifies the heteroscedasticity causes because the variance of error differs with the regressors.

Table 5: Breuch-Pagan / Cook Weisberg test

\begin{tabular}{lll}
\hline Statistics & GL & NL \\
\hline Chi-square(1) & 0.75 & 0.02 \\
Prob $>$ chi $^{2}$ & 0.385 & 0.900 \\
\hline
\end{tabular}

The result of this test highlights that there is no issue of heteroscedasticity in the two models i.e. GL and NL having insignificant "p" values, because of which null hypothesis of "constant variance" is accepted.

Table 6: Wooldridge test

\begin{tabular}{lll}
\hline Statistics & GL & NL \\
\hline $\mathrm{F}(1,24)$ & 48.101 & 92.281 \\
Prob> F & 0.000 & 0.000 \\
\hline
\end{tabular}

To check the problem of serial correlation Wooldridge test is used. This test diagnoses for existence or absence of serial correlation in the panel data model, presented by (Wooldridge, 2010). Nonexistence of serial correlation in the idiosyncratic error is stated in null hypothesis, which is tested against the alternative hypothesis of presence of this correlation. Table 6 highlights the test results for both models, which pointed out serial correlation in the GL and NL model because of having correlation in the idiosyncratic error term of this model as evident from the significant probability value of all models, causes the rejection of null hypothesis.

\section{Conclusion and Policy Implications}

The findings of the study suggest that conventional banks in Pakistan are reaping the benefits of credit growth through the utilization of innovative credit derivatives. However, Islamic banks are still impartial towards the use of derivative contracts. Mostly Islamic banks are engaged in the limited use of future contracts to hedge their financing risk which translate into insignificant impact on their financing portfolio. Therefore, it is recommended to introduce innovative shariah compliant credit risk transfer instruments in Islamic Banks of Pakistan as practised in other Muslim countries to boost their financing portfolio. It is also recommended to enhance the lending performance of commercial banks to build up strategies for managing their lending portfolio more effectively by using innovative risk transfer techniques. 


\section{References}

Afza, T., \& Alam, A. (2011). Corporate derivatives and foreign exchange risk management: A case study of non-financial firms of Pakistan. The Journal of Risk Finance, 12(5), 409-420.

Ahmad, A., Malik, M. I., \& Humayoun, A. A. (2010). Banking developments in Pakistan: A journey from conventional to Islamic banking. European Journal of Social Sciences, 17(1), 12-17.

Ahmed, H., \& Khan, T. (2007). 10 Risk management in Islamic banking. Handbook of Islamic banking, 144.

Aisen, M. A., \& Franken, M. (2010). Bank credit during the 2008 financial crisis: A cross-country comparison: International Monetary Fund.

Akhtar, M. F., Ali, K., \& Sadaqat, S. (2011). Liquidity risk management: a comparative study between conventional and Islamic banks of Pakistan. Interdisciplinary Journal of Research in Business, 1(1), 35-44.

Akhtar, S. (2006). Financial sector of Pakistan-the roadmap. Islamic finance news, $3(16), 26$.

Ali, A. E. (2015). Impact of Credit Risk Transfer on Islamic Bank Lending Behavior and Financial Stability. Working Paper Series.

Allen, F., \& Gale, D. (2004). Competition and financial stability. Journal of Money, Credit, and banking, 36(3), 453-480.

Angora, A., \& Roulet, C. (2011). Transformation risk and its determinants: A new approach based on the Basel III liquidity management framework. Universite de Limoges.

Arping, S. (2004). Credit protection and lending relationships.

Beck, T. (2000). Financial structure and economic development: Firm, industry, and country evidence (Vol. 2423): World Bank Publications.

Bedendoa, M., \& Bruno, B. (2009). Credit risk transfer practices in US commercial banks: Citeseer.

Berrospide, J. M., \& Edge, R. M. (2010). The effects of bank capital on lending: What do we know, and what does it mean?

Bokpin, G. A., \& Isshaq, Z. (2009). Corporate governance, disclosure and foreign share ownership on the Ghana Stock Exchange. Managerial Auditing Journal, 24(7), 688-703.

Breusch, T. S., \& Pagan, A. R. (1979). A simple test for heteroscedasticity and random coefficient variation. Econometrica: Journal of the Econometric Society, 12871294.

Cebenoyan, A. S., \& Strahan, P. E. (2004). Risk management, capital structure and lending at banks. Journal of banking \& finance, 28(1), 19-43.

Chernykh, L., \& Theodossiou, A. K. (2015). Determinants of bank long-term lending behavior: Evidence from Russia.

Chodechai, S. (2004). Determinants of Bank Lending in Thailand: An Empirical Examination for the years 1992-1996. Unpublished Thesis. 
Cihák, M. M., \& Hesse, H. (2008). Islamic banks and financial stability: An empirical analysis: International Monetary Fund.

Cook, R. D., \& Weisberg, S. (1983). Diagnostics for heteroscedasticity in regression. Biometrika, 70(1), 1-10.

Cucinelli, D. (2013). The determinants of bank liquidity risk within the context of euro area. Interdisciplinary Journal of Research in Business, 2(10), 51-64.

Demirgüç-Kunt, A., \& Levine, R. (2004). Financial structure and economic growth: A cross-country comparison of banks, markets, and development: MIT press.

DUFFIE, D. (2007). Innovations in credit risk transfer: Implications for financial stability, mimeograph, 2 July.

Farrar, D. E., \& Glauber, R. R. (1967). Multicollinearity in regression analysis: the problem revisited. The Review of Economic and Statistics, 92-107.

Forum, J. (2008). Credit Risk Transfer - Developments from 2005 to 2007. In B. f. I. Settlements (Ed.): Bank for International Settlements.

Goderis, B., Marsh, I. W., Castello, J. V., \& Wagner, W. (2007). Bank behaviour with access to credit risk transfer markets.

Greenspan, A. (2005). Risk transfer and financial stability: a speech to the Federal Reserve Bank of Chicago's Forty-first Annual Conference on Bank Structure, Chicago, Illinois (via satellite), May 5, 2005.

Gurley, J. G., \& Shaw, E. S. (1967). Financial structure and economic development. Economic development and cultural change, 15(3), 257-268.

Haensel, D., \& Krahnen, J. (2007). Does credit securitization reduce bank risk? Evidence from the European CDO market.

Hirtle, B. (2009). Credit derivatives and bank credit supply. Journal of Financial Intermediation, 18(2), 125-150.

Imran, K., \& Nishat, M. (2013). Determinants of bank credit in Pakistan: A supply side approach. Economic Modelling, 35, 384-390.

Kairu, P. (2009). Credit Management. Focus Publishers Ltd Nairobi.

Khan, N., Ali, K., Kiran, A., Mubeen, R., Khan, Z., \& Ali, N. (2016). Factors that Affect the Derivatives Usage of Non-Financial Listed Firms of Pakistan to Hedge Foreign Exchange Exposure. Journal of Banking and Financial Dynamics, 1(1), 9-20.

McKinnon, R., \& Shaw, E. (1973). Financial deepening in economic development. Washington, Brookings Institution.

McKinnon, R. I. (2010). Money and capital in economic development: Brookings Institution Press.

Nicolo, A., \& Pelizzon, L. (2006). Credit derivatives: Capital requirements and strategic contracting.

Olokoyo, F. O. (2011). Determinants of commercial banks' lending behavior in Nigeria. International Journal of Financial Research, 2(2), 61.

Paroush, J., \& Schreiber, B. (2008). The Relationships Between Profitability, Capital, and Risk: Commercial vs. Saving/Mortgage Banks. 
Rai, K., \& Kamil, H. (2010). The global credit crunch and foreign banks' lending to emerging markets: why did Latin America fare better? : International Monetary Fund.

Ramzan, M., \& Zafar, M. I. (2014). Liquidity risk management in Islamic banks: a study of Islamic banks of Pakistan. interdisciplinary journal of contemporary research in business, 5(12), 199-215.

Rehman, A., \& Cheema, A. (2013). Financial Development and Real Sector Growth in Pakistan. interdisciplinary journal of contemporary research in business, 5(1), 618-636.

Rodríguez, F., \& Carbó, S. (2000). Microeconomic determinants of bank lending: An application to the Spanish case. Paper presented at the The 3rd Meeting of Applied Economics Conference, Valencia.

Roman, A., \& Şargu, A. C. (2014). Banks liquidity risk analysis in the new European Union member countries: Evidence from Bulgaria and Romania. Procedia Economics and Finance, 15, 569-576.

Stepanyan, V., \& Guo, K. (2011). Determinants of bank credit in emerging market economies: International Monetary Fund.

Wagner, W., \& Marsh, I. W. (2006). Credit risk transfer and financial sector stability. Journal of Financial Stability, 2(2), 173-193.

White, H. (1980). A heteroskedasticity-consistent covariance matrix estimator and a direct test for heteroskedasticity. Econometrica: Journal of the Econometric Society, 817-838.

Wooldridge, J. M. (2010). Econometric analysis of cross section and panel data: MIT press.

Zahan, M., \& S Kenett, R. (2012). Hedging instruments in conventional and Islamic finance. Electronic Journal of Applied Statistical Analysis: Decision Support Systems and Services Evaluation, 3(1), 59-74.

Zakaria, \& Ismail. (2007). Securitization and the Stability in Islamic Banks. Paper presented at the MFA 9th Conference. 